\title{
The teaching of Suryomentaram as the sources of parenting practice in cultivating empathy among children to reduce bullying
}

\author{
Berta Esti Ari Prasetya \\ Universitas Kristen Satya Wacana \\ Salatiga, Indonesia \\ Bertaprasetya@gmail.com
}

\begin{abstract}
Bullying has been considered as one problem in children's social behavior. Promoting empathy among children has been recorded as one effort to reduce bullying act. Empathy is considered as important factor in pro social behavior, it moderates aggressive behavior, establishes and maintains friendships, reduces acting-out behaviors in children and has other beneficial impacts on individuals. It is therefore, empathy needs to be developed in children so that they may have all the benefits of this character that in turn may reduce the tendency of participating in bullying behavior. Since empathy is developed with age, parents need to include this in their parenting practices. In an effort to develop empathy in children, Indonesia has many local wisdoms that can be the sources of the teaching/parenting program for children. Utilizing local wisdom as the sources in parenting practice is believed to be effective since it is not only developing noble character in individuals, it even more may become the uniqueness or strength of a nation. One of the local wisdom in Java that is loaded with teachings about empathy values is shared by Suryomentaram. According to the teachings of Suryomentaram, noble individuals are those who have the ability to understand the feelings of others, as if it were experienced by him/herself. This article will discuss about Suryomentaram's teachings on developing empathy in children and how parents can utilize these values in their everyday parenting practice. This article is a literature reviews based on Suryomentaram writings and other articles that add to Suryomentaram original writing.
\end{abstract}

Keywords - Suryomentaram's teachings, empathy, parenting practice.

\section{INTRODUCTION}

A data on Minister of Education Exposure [1] mentioned that $84 \%$ students in Indonesia have experienced as the victim of bullying behavior in school at least once, meanwhile $75 \%$ of the students admitted that he/she has been conducted a violence act in school at least once. Other data reported by UNICEF 2014 mentioned that in Indonesia, 40\% of the students aged 13-15 years old reported that they have experienced violence behavior in school inflicted by their peers and the data raised to $50 \%$ in 2015. Meanwhile, Indonesia schools were reported 1.480 cases of bullying in 2014 by data from Komisi Perlindungan Anak Indonesia (The Indonesian Commission for Children Protection) [2]. This data indicates that Indonesia has a high prevalence of bullying cases.

The above condition should raise an awareness since the impacts of bullying has been reported as devastating for the development of children, either children as perpetrators of bullying [3][4][5] or even more as bullying victims. It was also observed that the children who were once victims of bullying were likely to become the next bullying perpetrators if they left untreated [6]. Considering this, we need to advocate a serious effort in order to reduce the bullying case. Currently the handling of bullying has also been declared as an important program for Indonesia's government, as stated in Indonesian ministry of education and culture regulations no.82/2015 a program under the Violence Prevention and Intervention in Education Unit by the Minister of Education of Indonesia.

In a research conducted by Murti [7], it was found that bullying perpetuators tend to have an inability to empathize, inability to see other person's point of view, and inability to recognize the feelings of others. These result supports the research done by Baumeister, Smart and Boden [8] who found that children who engaged in bullying behaviors tend to lack of empathy, tend to be manipulative, and seek profit for themselves in their interpersonal relationships. Meanwhile, researches done by Gini, Albiero, Benelli, and Altoè [9] and one done by Jolliffe and Farrington [10] found that bullying behavior is associated with low levels of empathy among the bullies. Given the above, it is plausible to say that to reduce the prevalence of bullying cases we need to improve the ability to empathize in children. One way to do that is by providing a character building education among the children to improve empathy, in the hope that the increase of empathy in children will decrease their tendency to bully others [11].

A character building program can be done through a parenting practice by parents. As Murti's research [7] found that the education practice done by parents is crucial to provide the foundation for intellectual, emotional social development, including empathy, and moral development in children. This is also in line with that was asserted by Koestner \& Franz [12] who found in their study that there was a strong relationship between early childbearing patterns with children's empathic concern.

This research is done under KEMENRISTEK-DIKTI sponsorship: Hibah Penelitian Terapan 2017 
Wagiran [13], Gunawan [14] and Fajarini [15] asserted that effective character building program needs to incorporate local wisdom as the sources of the teachings. Among many local wisdoms that Indonesia has, there is one which is loaded with noble values on how to relate with others with empathy, developed by Suryomentaram [16]. The teachings has been practiced by a group of people around Salatiga, Central Java Indonesia until now.

Using local wisdom as sources of teaching has an advantage since it is part of the culture. It is possible that the intervention using values of local wisdom will be more natural because it does not need to introduce new values, so the chances of success will be better since the community is familiar with the values already.

In addition to the above, using local wisdom as the sources of parenting values for children also allows preservation of noble cultures of Indonesia [14]. Local wisdom will only be sustainable if practiced in everyday life and not just kept as an ancient treasure that is considered unreached [13]. Without a revitalization effort, this local wisdom that full of virtues will be vanquished by the globalization wave [15].

Considering all of the above, this article intends to explore the local wisdom of Suryomentaram which has an educational content of empathetic attitude so that this material can be used for parenting practice in everyday life, in developing empathy in children.

\section{II.LITERATURE REVIEW}

\section{A. Background of Ki Ageng Suryomentaram's Life.}

Ki Ageng Suryomentaram was born named Bendoro Raden Mas Kudiarmadji, on May 20, 1892, as the son of Sri Sultan Hamengkubuwono VII (1839-1921) and Bendoro Raden Ayu Retnomandojo. His mother was the daughter of Patih Danurejo VI. Suryomentaram is listed as the 56th son of the 79th son of Sri Sultan [16].

Suryomentaram seemed to spend his childhood from a well-off family, but in the reality he was the son of a sultan and grandson of a patih (Prime minister in Javanese palace) [17]. He also featured as someone who had an intellectual capacity, and seemed to show great interest in learning language, which was demonstrated by his ability in Dutch, English and Arabic. He also learnt theology of Islam under the supervision of Kyai Haji Ahmad Dahlan, who was one of the most important Islamic leaders in Indonesia. However, Suryomentaram also seemed to show some interests in the philosophical sciences that he acquired from various sources.

By the time he was 18 years old, he obtained a new title, Prince Haryo Suryomentaram and had the opportunity to work in the governor's office for 2 years. At this point, he had the opportunity to see the real condition of the people who were still under Dutch colonialism. This along with the various information he had learned from his religious knowledge, philosophy and anxieties of his own contemplation, became the triggers of his desire to leave the palace. At the time when Sultan HB VII was crowned as a new Sultan, finally this new sultan allowed Suryomentaram to leave the palace. He then decided to stay in Bringin Salatiga village, becoming a farmer. That was the time he created his well-known thoughts called Ilmu Jiwa or Kawruh Jiwa translated as The Knowledge of the Soul/Mind [17]. Next, he led a movement called the Movement of Knowledge of Fortune [16].

Suryomentaram also recorded to be involved actively in the development of education in Indonesia. It was proven by his involvement in promoting education in Indonesia together with Ki Hadjar Dewantara, one of prominent figures in education in Indonesia. Suryomentaram offered his house to be used for $\mathrm{Ki}$ Hadjar Dewantara's education hall [17]. Furthermore, he took a role in education movement for adults, called "The independent Souls" [16].

\section{B. Individual Development by Suryomentaram}

According to Suryomentaram, life is a process of travel that leads to the highest achievement of the discovery of selfknowledge. This process begins at the time of birth and when the baby learn about the physical and material consciousness, which then develops into psychological awareness (emotional, mental, and intellectual). The peak of one's growth is when the individual reaches maturity which is when the individual reaches Spiritual awareness [18]

Prihartanti [18] describes the structure of the soul/mind according to Kawruh Jiwa is as follows:

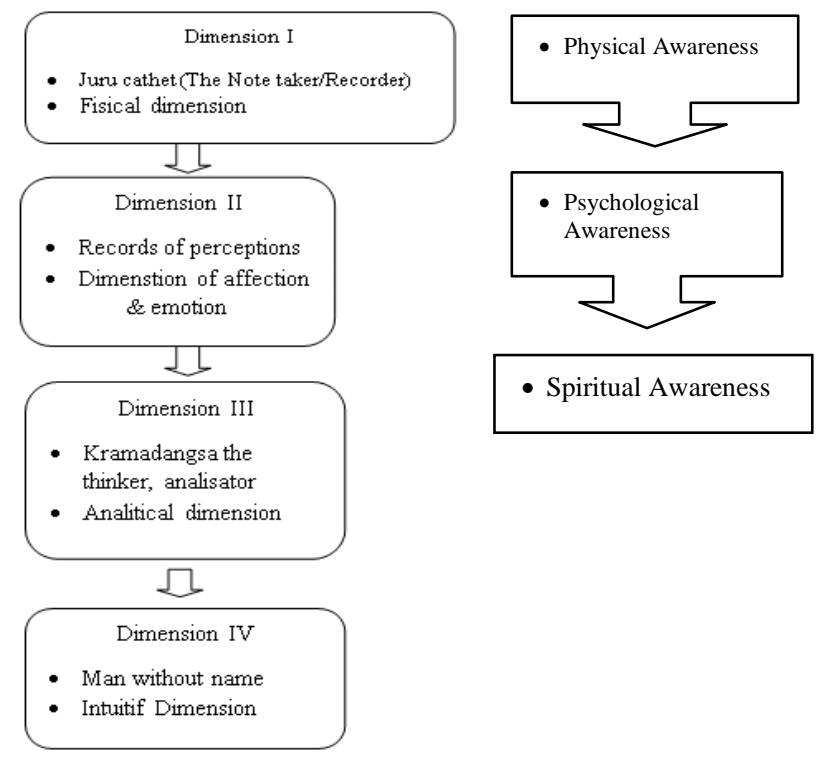

Figure 1. Structure of Soul/Mind according to Kawruh Jiwa

Suryomentaram [16] mentioned that dimension $I$ is the dimension of the newborn. In this dimension the baby is only able to feel the environment without being able to provide an active response. Suppose the baby can only feel the heat, cold, but without being able to move his own body to protect from heat and cold. In this dimension I the individual only observe passively, simply as a recorder. Individuals only record what are felt physically. Next, individual will grow to Dimension II. In this second dimension, a child is able to react to what he has experienced, but still do not understand the laws that apply 
to the universe. For example, a child who sees fire and is happy, then he wants to play with it, without understanding the "law" that the fire is hot and when it is touched, it may burn the skin and the child may get hurt. From this example, it appears that the child can respond, but the response is still without the understanding of the law. Followed by dimension III is an individual who already understands the laws that apply in the universe. But in this dimension, the individual just stops at the cognitive level. He may be able to perform a variety of analytical skills but ignoring one important aspect which is the law of "feeling". Only people who can reach the dimension IV are the ones who start paying attention to "the feeling". These persons believe that it is not enough mastering merely analysis skill, but people need to take into account on how other people's feelings. Thus, the highest development of the individual is when the individual also considers the feelings of others who interact with him / her.

Individuals who are living in the dimension IV are individuals who have been able to achieve complete capabilities. The individual will be able to pay attention to what is happening to him in his interactions with other people or things outside himself, understanding the laws that apply to the interaction, observing his own feelings, analyzing them, but also paying attention to how the "feelings" of others (empathetic towards other people). This according to Suryomentaram will bring to an important slogan, "The true comfort comes from making other people comfortable; true happiness comes from making other people happy."

\section{Suryomentaram's Concept about How to Live with Others}

Teaching empathy to children can be started by introducing them about our role, our position, and contribution to the society. It means that children need to learn, that we are part of the society and whatever that we do will affect the society around us, and in turn will come back to ourselves.

In terms of understanding about social interaction, Suryomentaram [19] asserted that there are three kinds of living creatures, namely humans, animals and plants. Each has a sense for life. This sense of life will encourage someone to move. Example: when people are looking for a drink this is because humans are driven by their thirst. Thus it can be said that every human action is driven by a "feeling" or a will.

Furthermore Suryomentaram [19] mentioned that there are two types of animals. One is animals that live as solitaires and animals that live in a group. Examples of solitaire types are geckos, beetles, spiders, snakes etc. While example of animals that live in a group are ants, bees, termites. They are born that way and we cannot change it. Even if we push them to change, it may bring death to the animals. For example, beetle naturally live alone as a solitaire, when it is forced to live in groups of beetles, they will fight each other and may die. The same thing happen with animals that live in groups, if they are forced to live alone they may also experience death because they are accustomed to do things together in a group. Animals that live in groups usually have certain duties in life, so that if any of them is not exist anymore, it will disrupt the harmony of life and even the survival of life together. For example, ants, some are assigned as queens, as workers, as egg layers etc. where each has a duty for the survival of the species of ants. If there are no workers, the survival of ant species may be threatened.

Referring to this, humans belong to the kind of living beings who naturally live in groups. In this group, humans need to work together and need a sense of unity with others. This is important because basically humans always need the presence of others in their life. Even for the simplest thing, human needs other people. For example, if a question is posed to a child, "There is rice on your plate, whose work is that?" The child may reply: the work of farmers. But if we traced more carefully, the presence of rice on the plate is the work of many people. To be able to present rice on a plate, farmers cannot hoe the land to plant paddy without the help of the blacksmith who makes the eyes hoe. For hoe to be used well, it requires the work of a carpenter to make the proper hoe handles. Even when the paddy has turned to yellow, we will need people to harvest it, and do many things to make rice. When it becomes rice, we will need other people to bring the rice to the market so that we may be able to buy it easily. From this example, it is showed that even for a simple thing the presence of rice on the plate, it takes many individuals who contribute to bring it there. And when one element is eliminated, it will disturb the process of presenting the rice on a plate. This shows that to be able to continue living, human will always need others.

Suryomentaram also mentioned the importance of knowing or understanding other people's characteristic, or the characteristic of the object that we interact with. For example: when individuals want to interact with fire. Then, the person must understand the nature of fire in order to interact well with fire. For example since the fire is hot, then someone are not supposed to touch the fire. By understanding the character of fire, then the individual will be able to interact with the fire appropriately. Even sometimes we do not complain when there's something that is not expected happened. For example, when someone sees that his hands get burnt, he will not be angry to the fire, because he knows that hot is the characteristic of fire. This also applies when individuals interact with others. Individuals need to understand the character of others so that individuals can interact with them successfully and harmoniously [19].

Furthermore, Suryomentaram [19] also mentioned that to be able to know other people, the individual needs to understand in advance what "human" is. According to Suryomentaram, human nature is a good/thing that have "feelings". Therefore, attention to the "feeling" of human beings is important in interacting with others. If man is made up of eyes, nose, mouth and hand, but does not have "feeling" then it is no different from the "bathang" or corpse/corpse. Therefore, we need to keep in mind that when individuals interact with others it should be remembered that other people have "feeling" rather than just a flabby corpse. 
In relation to the "feeling" of human beings, there are many feelings possessed by the individual, but basically it can be classified in two types: namely comfort (sekeca) and discomfort (mboten sekeca) [19].

Furthermore, it is mentioned that interaction with others may result in feeling of "comfortable" or "uncomfortable". According to Suryomentaram, disputes happen basically due to the fact that individuals are not trying to understand the "feelings" of others. When individuals are able to understand the feelings of others, then disputes will not happen. Nevertheless it is said that often the individual has difficulty to understand the feeling of others because it is blocked by the individual's own feeling. Therefore, the individual must recognize what it is that hinders his ability to recognize the feelings of others. This can be done by self-examination or self-reflection.

\section{Suryomentaram's concept about Mawas Diri: Introspection.}

In Suryomentaram's concept of introspection or Mawas Diri, Suryomentaram emphasizes the importance of "pangawikan pribadi" or self-study about one' self or knowledge of self. It is the effort to continually recognize oneself or to be self-reflective about one's need. In the absence "pangawikan pribadi", the individual will have a confused knowledge of himself, which in turn will lead to mental health disorders.

In terms of self-knowledge, according to Suryomentaram, man consists of three measuring instruments [20], namely: the five senses, feeling (rasa), and understanding (pangertos). In this case, to have an introspective attitude (mawas diri), man needs to recognize how his senses are, what he thinks and how his understanding or mindset is about things that happen within him. In this case, the individual needs to understand: what his senses are experiencing, what he feels, and what he thinks about it. In the context of their interaction with others, the individual also needs to pay attention to what the senses are experiencing by others, what others feel and what other people think when interacting with the individual.

In Suryomentaram's [19] theory of interaction with others, Suryomentaram conveyed that often times when someone is dealing with others, he forgot to pay attention to how he reacted to the other person. Suryomentaram said that when dealing with other people, he/she tends to just put other people as the object of his/her attention alone in the interaction, and ignore the feelings that is felt about the interaction. In relation to this, Suryomentaram emphasizes the importance of introspection, namely the willingness to observe oneself, what the feeling that he has when he is interacting with other people. For example, when meeting (methuki) a bright light, at the time the individual wants to read, then it is the "feeling happy" who is meeting with the lamp. In such condition, the individual will tend to judge that the lamp is good. But if the individual meet the lights in a state of wanting to sleep, then "dislike / hate" is the feeling that will meet with the light. In this condition, the individual will assess the light as a negative thing. Thus, what Suryomentaram wants to emphasize here is that, when dealing with others, there will be two possible feeling that he/she has for others, which are: the feeling of like or dislike. By understanding what he is feeling in the moment of interaction with other, the individual will be able to understand that what he feels in interacting with others can come from his own "feeling". It is possible that when he judge other people as good or bad, it may actually come from his own feelings towards the person. If the individual does not pay attention to this, it can lead to false conclusions about other people's intentions, or the feelings of others in interacting with him / her.

Self-awareness is something that can be trained [18]. This can be done by continuing to observe whether the individual has acted "sabutuhe, saperlune, sacukupe, samestine, sakepenake, and sabenere" (as necessary and appropriate). The first three terms: sabutuhe, saperlune, sacukupe, describe the discipline of life. People need to limit when he needs and not to be excessive. Sakepenake talk about people not need to be very ambitious and stress-out themselves very hard. While sakbenere and samestine talked about the idea that people need to act according to what is right, fair, and in accord with the existing moral rules. The desire to fulfill the excessive needs, but ignoring what is right and fair, in turn will make the individual to become too self-centered. This kind of person will be unwilling to care about the "feelings" of others and if he cares, it is only for the fulfillment of his own needs.

Suryomentaram [16] also stressed the need to pay attention to the "notes" recorded by "the I" from childhood until now. Attention to the note will help the individual to be able to act properly. According to Suryomentaram there are 11 important notes, but in this article the writer will only discussed 2 notes, namely: Note of honor and Note of Power.

- Note of honor. According to Suryomentaram [16], individual's believe about honor is often inappropriate or even false. For example, "Individuals often think that it feels good to be respected ". If these are the notes that are recorded in individual's mind, then the people will seek various ways to be respected that sometimes do not use an acceptable way. For example by doing the act of bullying in order to gain respect from the victims. Yet according to Suryomentaram, the right note should be: "It feels good to respect others". With this note or believe, the individual does not have to wait for others to respect them. They do not need to force others to respect them by committing bullying act. On the contrary, it is better to respect others first to generate respect for themselves and to form a mutual relationship. This kind of respect is believed to be more long lasting and genuine.

- Notes of power. Suryomentaram [16] also mentioned that often times individuals make a false believe about power. The notes of power often read "It feels good to have power over other people ". But the proper believe should be, "If we make other people feel comfortable, people will trust us, and give us that power ". That is, if the individual 
makes other people feel comfortable, in this case paying attention and giving what others' needs, chances are other people will give their trust, and even give the power to lead them. In the context of bullying behavior, engaging in bullying to gain power from others will be regarded as counterproductive actions.

\section{APPLICATION}

From the above described teachings of Suryamentaram, there are several principles that can be the source of parenting practice. These principles can be used by parents in developing the children's ability to relate to others, developing empathy, which in turn can be used to reduce bullying behavior.

Firstly, children need to be taught the importance of a sense of unity, which emphasizes the importance of understanding that a child is part of a bigger society and contributes significantly to the survival of society. In this case, the child needs to be taught that each individual is a valuable individual and will provide benefits and functions in society. Children need to be educated to respect others, to see others as individuals who can contribute to the common life together. This is also in line with what Adler [21] has to say about social interests that speak of the individual's willingness to see that he or she needs to contribute to society, and that selfachievements are meaningful only when considering the benefits to society.

Secondly, the child needs to be taught that for a successful relationship, a child needs to pay attention to the 'feelings' of others, but at the same time also needs to be an observer of his own feelings. The observation of his or her own feelings can be seen when he/she is interacting with others. The children need to evaluate when they interact with others, do they start by a feeling of like or dislike towards others. Instead of blaming others for an uncomfortable relationship, a child needs to learn to observe that it may actually his own feelings that create an uncomfortable situation for their relationship.

Thirdly, the child also needs to be taught that for a successful relationship, a child needs to learn about the other person as well. They need to understand other person's traits, needs, what they like and dislikes, so that the individual can relate to the other person accordingly. The willingness to understand what is going on with other people's life will create an attitude of empathy for their feelings, their suffering, and other people's experiences that make the individual have more tolerance towards others, and also acceptance for the way they are.

Fourth, children need to be reminded that the inability of the individual to recognize the feelings of others (empathy) occurs because the individual is preoccupied with his own feelings to fulfill their own needs, so that they do not have room to care about other people's feelings. Therefore, the children need to be reminded the importance of discipline to limit what their desires only to what is necessary, so that it will not be too excessive (sakcukupe, sakperlune, sakbutuhe), they do not need to be too hard on themselves in achieving something but ignoring what is right (sakpenake), but they are supposed to fulfill their needs in the right way and in accordance to the moral rules (sakbenere, sakmestine). By limiting oneself to the things that are necessary, the individual will have time and willingness to see what the needs of others. In this case they may be able to show empathy.

Fifth, children need to be taught to have a more productive philosophy in developing records of honor and records of power. We do not pursue to be respected and to have power over others by forcing others to do so (for example by doing bullying). In opposite, we need to firstly give others some respects and make other people's life comfortable, that in the end they will give us respects by doing that and give us their trust to lead them.

\section{IV.CONCLUSION}

Put it in a nutshell, there are several steps that parents can learn from Suryomentaram's teaching to use them as the sources of parenting practice in order to cultivate empathy in their children. It needs to be started from realization that human being are naturally living in a group and that every part of the group member has his/her own contribution to the community, it is therefore everyone is valuable and matters. In order to be able to improve empathy, children need to be able to understand themselves first and learn how to understand other people and other people's feeling. In order to be willing to understand other people's feeling, the children need to learn to feel enough with what they have and not too greedy wanting many things excessively.

However, one thing needs to take into account in parenting practice is that children learn by an example. It is therefore, rather than just teaching children about how to be empathetic to others, parents need to be a living example of how to be empathetic to their children and other people in general. Only then, the parenting practice about how to teach empathy can be effective.

\section{References}

[1] Indonesian's Education Minister. “Exposure of Indonesian's Education Minister", Internet: www.kemdikbud.go.id/.../045778be5c791af7d8d59e460827bd75, Jan. 15, 2016. [Aug. 1, 2017]

[2] Republika Online. "Aduan Bullying Tertinggi." Internet: http://www.republika.co.id/berita/koran/halaman-1/14/10/15/ndh4spaduan-bullying-tertinggi, Oct. 15, 2014 [Dec, 22, 2014

[3] K. Rigby., and P.T. Slee. "Dimensions of interpersonal relations among Australian school children and their implications for psychological wellbeing.” Journal of Social Psychology, vol. 133, pp. 33-42, 1993.

[4] B.J. Kochenderfer., and G.W. Ladd. "Peer victimization: Cause or consequence of school maladjustment?" Child Development, vol. 67, pp. 1305-1317, 1996.

[5] T.R. Nansel., M. Overpeck, R.S. Pilla., W.J. Ruan., S.B. Morton., and P. Scheidt. "Bullying behavior among U.S. youth: Prevalence and association with psychosocial adjustment." Journal of the American Medical Association, vol. 285, pp. 2094-2100, 2001..

[6] B. Vossekuil., R.A. Fein., M. Reddy., R. Borum., and W. Modzeleski. The final report and findings of the safe school initiative : implications 
for the prevention of school attacks in The united states united States Secret Service and United States Department of Education. Washington, D.C, 2002.

[7] H.A.S. Murti. Dinamika Psikologis Empati Pelaku Bullying di Sekolah Menengah Atas di Yogyakarta: Manuscript. Yogyakarta, Satya Wacana Christian University, 2011.

[8] R.F. Baumeister., L. Smart., and J.M. Boden. "Relation of threatened egotism to violence and aggression: The dark side of high self-esteem." Psychological Review, vol. 103, pp. 5-33, 1996.

[9] G. Gini., P. Albiero., B. Benelli., and G. Altoe. "Does Empathy Predict Adolescents' Bullying and Defending Behavior?" Aggressive Behavior, vol. 3, pp. 467-476, 2007.

[10] D. Jolliffe., and D.P. Farrington. "Is Low Emphaty Related To Bullying After Controlling For Individual and Social Background Variables?" Journal of Adolescence, vol. 34, pp. 59-71, 2011.

[11] Y. Özkan., and G. Cifci. "The Effect of Empathy Level on Peer Bullying in Schools." Humanity \& Social Sciences Journal, vol. 4, pp. 31-38, 2009.

[12] R. Koestner and C. Franz. "The Family Origins of Emphatic Concern: a 26 Years Longitudinal Study." Journal of Personality and Social Psychology, vol. 58, pp. 709-717, 1990.
[13] Wagiran. (2012). "Pengembangan Karakter Berbasis Kearifan LokalHamemayu Hayuning Bawana (Identifikasi Nilai-Nilai Karakter Berbasis Budaya)." Jurnal Pendidikan Karakter, Vol. 3, pp. 329-339, Oct. 2012.

[14] I. Gunawan. (2012). "Mengembangkan Karakter Bangsa Berdasarkan $\begin{array}{lll}\text { Kearifan Lokal". } \quad \text { OOn-Line]. } & \text { Avaliable: }\end{array}$ https://publikasiilmiah.ums.ac.id/bitstream/handle/11617/1672/Imam\%2 0Gunawan.pdf?sequence $=1$ [Dec. 12, 2014].

[15] U. Fajarini. "Peranan Kearifan Lokal Dalam Pendidikan Karakter." Sosio Didaktika, vol. 1, Pp. 123-130, Des. 2014.

[16] K. Fudyartanto. Psikologi Kepribadian Timur. Yogyakarta, Pustaka Pelajar, 2003.

[17] K. Suparno. Raos Persatuan. Presented at "Sekolah Kawruh Jiwo". Yogyakarta, 2015.

[18] N. Prihartanti. Manusia Tanpa Ciri. Presented at "Sekolah Karuh Jiwo," Yogyakarta, 2015.

[19] Suryomentaram. Kawruh Jiwa. Jakarta, CV. Haji Masagung, 1990.

[20] S. Waringah. Dinamika Manusia. Paper Presented at "Sekolah Kawruh Jiwo", Yogyakarta, 2015.

[21] J. Feist and J.F. Gregory. Theories of Personality $6^{\text {th }}$ ed. Yogyakarta, Pustaka Pelajar, 2008. 